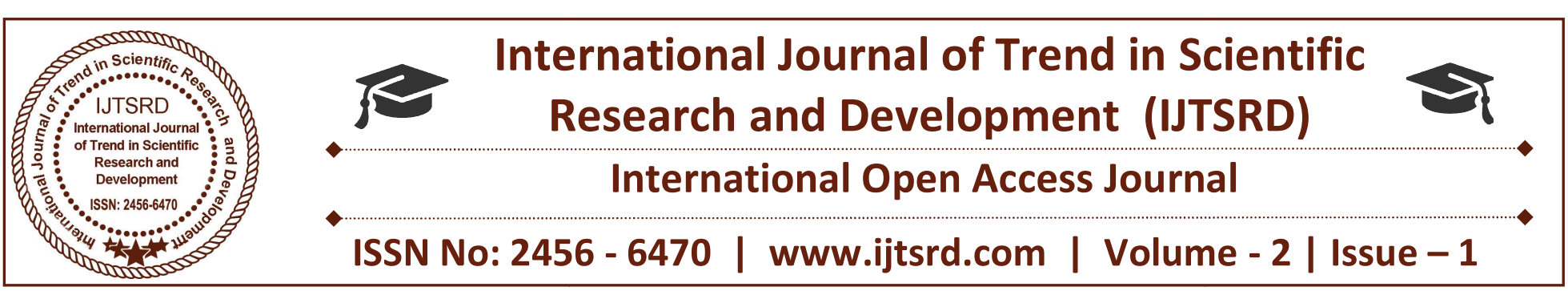

\title{
The Relationship and Effect of Role Overload, Role Ambiguity, Work-Life Balance and Career Development on Work Stress among Call Center Executives of Business Process Outsourcing (BPO) in Selangor
}

\author{
Abdul Jumaat Mahajar \\ Manipal International University \\ School of Management and Business \\ Nilai, N.Sembilan
}

\author{
Jasmani Mohd Yunus \\ Universiti Utara Malaysia \\ College of Business \\ Sintok, Kedah
}

\begin{abstract}
This research aim to identify the contributing factors of work stress to recognize the effect of highly influencing stressor among call center executives of BPO in Selangor. The four independent variables of this study which consist of role overload, role ambiguity, career development and work-life balance are analyzed to determine the relationship with dependent variable of work stress. A total 152 of respondents were involved in this study. Data collection was carried out by distributing questionnaires. The research analysis are consist of descriptive statistics, reliability analysis and inferential analysis to identify the relationship among the independent and dependent variables. The four independent variables together, explain 65 percent of the variance on stress. Role overload seems to have the greatest influence on stress, judged by the Beta weight of .784 which is the highest., followed by career development Beta of .21. Work-life balance also has a significant negative influence on stress (Beta of -.21). Meaning, when work-life increase stress will decrease. Do not individually explain the variance on stress level significantly (Beta of. $0.0770 \mathrm{p}>0.05$ ). So stress will increase if role overload and career development are increase. But for work life balance when it is increase the stress level of the call center executive in BPO decreased.
\end{abstract}

Keywords: work stress, role overload, role ambiguity, career development, work-life balance

\subsection{INTRODUCTION}

Job stress is determined as a human's physical and mental responses or feedback of changes or certain environment. Occupational stress may result from several factors including, psychological, physical and environmental. According to Lehrer et al. (2009) it is found that severe and lasting physical factors, psychological condition and social stressor are contributing stress. Work stress arises among the employees due to stressor such as heavy work overload, lack of job security, interpersonal relationships in the workplace, role conflict and travelling stress. Stressors has been recognized as impacting the female and male employee's health (Days \& Livingstone, 2001). Work related stress may vary and the stress level is different based on the job type, job requirements and employee's capability to absorb. Stress across different occupations and roles has been discussed in many research with a number of different occupations being described as facing stress on the above average level, for instance, study of stress among teachers and nurses (Surinder, 2011; Wu et al. 2007). Especially, stress level in the Business Processing Outsourcing (BPO) industry differs compared to other industries as the job nature is based on client's needs.

Business process outsourcing (BPO) is the fast growing industry that accommodates the current business needs which focuses on cost saving. BPO encompasses 
outsourcing of the non-core activities like payment services, wellness program and call center (Latha \& Panchanatham, 2010). Malaysia also had joined the list of the top BPO destinations along with India, Philippines and China (Mike, 2015). Malaysia become one of the BPO destiny that mainly centralized and located in Selangor and Kuala Lumpur. BPO companies in Malaysia are increasing from year 2012 and the income fetched by BPO industry was RM 5 billion (Mike, 2013). Business Process Outsourcing is one of the most preferable employment source for the youngsters, though employees are unable to be retained for a longer period in the employment as the level of stress is very high and it leads to health problem. Business process outsourcing companies had created a highly demanding working environment which involve unrealistic work demand, poor working conditions, work-life conflict and career development. Business process outsourcing industry unable to retain their employees for long term employment due to occupational stress that need to be minimized.

\subsection{Problem statement}

Occupational stress is potential to contribute organizational incompetence, increased health care cost and reduce employee's performance. Prolonged work stress has directly led to negative impact to individuals and organizations in terms of productivity, health, cost and performance. Work related stress will produce a poor work life for an employee. According to the fourth edition of the European Working Survey that carried out in 2006, shows that $22 \%$ of European employees are encountering spinal pain, exhaustion and muscular pain owing to stress. Work stress are also linked with a few health issues that consist of cardiovascular diseases (Kivimaki \& his associates, 2002), neck-shoulder-armwrist-hand issues (Arien\& his associates, 2001), and musculoskeletal disorders mainly backbone difficulties (Hoogendoom \& his associates, 2000). There are inadequate studies that analyzing the work stress among BPO call centers in Malaysia. Therefore, this study will enable the management to identify the relationship and effect of role overload, role ambiguity, career development and work-life balance on work stress among executives in the BPO call centers that located in Selangor. This investigation will enhance the organization's ability to recognize the most influencing factor of work stress and to draw the stress management strategy.

\subsection{Research Objective}

The foremost objective of this study is to identify the relationship and effect of role overload, role ambiguity, career development and work-life balance on work stress in the call center of Business Process Outsourcing (BPO) industry. Deliberately, the detailed objectives of this study are as follows:

1. To investigate the relationship between role overload and work stress among call center executive of BPO industry in Selangor.

2. To investigate the relationship between role ambiguity and work stress among call center executive of BPO industry in Selangor.

3. To investigate the relationship between career development and work stress among call center executive of BPO industry in Selangor.

4. To investigate the relationship between work life balance and work stress among call center executive of BPO industry in Selangor.

5. To investigate the effects of role overload, role ambiguity, work-life balance and career development on work stress among the BPO call center executives in Selangor.

\subsection{Literature Review}

Role overload is caused by excessive demands that placed on the employees, which unable to be completed within the given time period. Role overload or work load is the major cause of work stress (Topper, 2007). According to Johnson et al (2005) role demands might be stressful when they are extreme which also known as role overload. Overload is evident in numerous domains, spillover effects often happen. Role overload exists when a person is given over numerous responsibilities or certain roles and tasks with short deadlines. Therefore, role overload results in stress and exhaustion (Conley \& Woosley, 2000). Dwyer and Fox's (2006) argued that role ambiguity is not directly leading to role stress if the employees have more role experience and have a clear idea on what is anticipated with their role. The previous study conducted shows that role ambiguity lead to work stress as positive relationship. According to a study conducted by Michie (2002), it is identified that career development has relationship with work stress as a contributing factor of work stress. Consequently, this will lead the individuals suffering from "career stress" and they are likely to show high frustration, job flexibility, exhaustion, poor work performance, and less effective interpersonal relationships at work (Ivancevich and 
Matteson, 2002). Career development is one of the stressor that led to work stress. Lack of attaining the anticipated career opportunity is the main reason for work stress. Career development is associated with poor promotion policies, job insecurity and poor pay within the organization (Sverke and Hellgren, 2002). Based on the studies conducted among construction workers by Loose and Waters (2004) it is identified that poor pay has a direct relationship to increases the levels of work stress. Based on drawing of Spillover theory by Zedeck, the study hypothesized that high levels of observed job pressure stress and job threat stress would forecast improved levels of work-life struggle, and declined levels of work-life balance. Mohan and Ashok (2011) explained that stress is frequently established when an individual is allocated a main accountability without appropriate power and allocation of power, interpersonal influences such as group cohesiveness, functional dependence, communication frequency, relative authority and organizational difference between role sender and focal persons. Work holism is associated with work stress and work-life imbalance, regardless of gender (Aziz and Cunningham, 2008). Work-life balance and job stress goes at the same time one to another. Employees give importance on pairing their lives and the effectiveness of workplace practices and policies in supporting them to accomplish such a goal (Ross \& Vasantha, 2014). Vijaya Lakshmi et al (2013), has studied and identified the problems of women faculty working in educational institutions. It is also determined that women faculty members suffered severe stress in the process of reaching work life balance.

\subsection{RESEARCH METHODOLOGY}

\subsection{Research Design}

Quantitative research design had been used for this study. According to Leedy and Ormrod (2001) quantitative research is expected to be precise in its measuring and investigation, as it proposed by the existing theories. Quantitative research upholds the hypotheses of an empiricist paradigm (Creswell, 2003). Quantitative research generally focuses on measuring social reality. According to Sukamolson (2007), he pointed that quantitative research questions are constructed to identify the quantities in approximately and to set up research numerically.

\subsection{Unit of Analysis}

Call center executives of BPO call center in Selangor is the unit of analysis for this study. Business process outsourcing is the fast growing industry in Malaysia. Malaysia has become one of the prefer country for Business Process Outsourcing Industry. BPO companies had created many job openings and generated more than RM 5 billion revenue by the growing demand on BPO (David, 2013). Along with China, India and Philippines, Malaysia was also certainly was benefited from the growing demand of BPO industry.

\subsection{Population and Sampling}

There is 150 call center executives working at Symphony BPO Solutions Sdn Bhd that is located in Petaling Jaya, Selangor. Total 100 call center executives is working in Aegis BPO Solutions Sdn Bhd that located in Petaling Jaya. Based on the sampling frame, there are total 250 call center executives working in the participating BPO call centers, Selangor. The sample size is based on the population table of Krejie and Morgan (1970). Therefore the applicable sample size for given population of 250 is $152(\mathrm{n})$. The survey form is retrieved from Google survey and was directly distributed to the Call center executives of (2) two different BPO Call Centers in Selangor. 


\subsection{Demographic Profile of Respondence}

Table 1: Profile of Respondents

\begin{tabular}{|c|c|c|c|}
\hline Demographic & Characteristics & Frequency & $\begin{array}{l}\text { Percentage } \\
(\%)\end{array}$ \\
\hline Gender & $\begin{array}{l}\text { Male } \\
\text { Female }\end{array}$ & $\begin{array}{l}60 \\
92\end{array}$ & $\begin{array}{l}39.5 \\
60.5\end{array}$ \\
\hline Age & $\begin{array}{l}24-34 \\
35-45 \\
46-56 \\
>56\end{array}$ & $\begin{array}{l}83 \\
36 \\
18 \\
15\end{array}$ & $\begin{array}{l}54.6 \\
23.7 \\
11.8 \\
9.9\end{array}$ \\
\hline $\begin{array}{ll}\text { Highest } & \text { Education } \\
\text { Qualification } & \end{array}$ & $\begin{array}{l}\text { Master } \\
\text { Bachelor Degree } \\
\text { Certificate / Diploma } \\
\text { Bachelor Degree } \\
\text { SPM / STPM }\end{array}$ & $\begin{array}{l}19 \\
79 \\
37 \\
21 \\
17\end{array}$ & $\begin{array}{l}12.5 \\
52.0 \\
24.3 \\
13.8 \\
11.2\end{array}$ \\
\hline Current Position & $\begin{array}{l}\text { Senior Manager } \\
\text { Manager } \\
\text { Assistant Manager } \\
\text { Senior Executive } \\
\text { Executive }\end{array}$ & $\begin{array}{l}8 \\
10 \\
2 \\
21 \\
43\end{array}$ & $\begin{array}{l}5.3 \\
6.6 \\
1.3 \\
13.8 \\
28.3\end{array}$ \\
\hline Length of Employment & $\begin{array}{l}\text { Below than } 2 \text { years } \\
2 \text { years to } 5 \text { years } \\
5 \text { years to } 10 \text { years } \\
\text { More than } 10 \text { years }\end{array}$ & $\begin{array}{l}59 \\
44 \\
39 \\
10\end{array}$ & $\begin{array}{l}38.8 \\
28.9 \\
25.7 \\
6.6\end{array}$ \\
\hline Type of Employment & $\begin{array}{l}\text { Permanent } \\
\text { Contract } \\
\text { Outsource (Agency) }\end{array}$ & $\begin{array}{l}126 \\
25 \\
1\end{array}$ & $\begin{array}{l}82.9 \\
16.4 \\
.7\end{array}$ \\
\hline Monthly Income (RM) & $\begin{array}{l}<2000 \\
2001-3000 \\
3001-4000 \\
4001-5000 \\
\quad>5001\end{array}$ & $\begin{array}{l}42 \\
52 \\
29 \\
5 \\
19\end{array}$ & $\begin{array}{l}27.6 \\
37.5 \\
19.1 \\
3.3 \\
12.5\end{array}$ \\
\hline
\end{tabular}

Table 1 shows the respondent's demographic characteristic. Frequency analysis shows that, 91 (59.9 \%) respondents were male and $61(40.1 \%)$ out of 152 respondents are female. The finding shows that majority of the respondents are between the ages of 19-29 years old (70.4\%). Frequency analysis on the highest qualification shows that majority $79(52.0 \%)$ of the call center executives are Bachelor Degree holders. In terms of current position, the analysis shows that majority of the respondents are from executive level which consist of 89 (58.6\%). Furthermore, the analysis on length employment found that majority of 69 (45.4\%) respondents had below than 2 years of service in BPO Call Center. Besides, the analysis on type of employment shows that 126 (82.9\%) respondents are on permanent employment. Lastly, it is revealed by the analysis that most of the BPO Call Center Executives are getting monthly income in the range of 2001 to 3000 which consist of 57 (37.5\%) respondents. 
International Journal of Trend in Scientific Research and Development (IJTSRD) ISSN: 2456-6470

\subsection{Correlation Analysis}

\section{Table 2:: Correlation Analysis results}

\begin{tabular}{|c|c|c|c|c|c|c|}
\hline \multicolumn{2}{|l|}{ Variables } & WS & $\mathbf{R O}$ & $\mathbf{R A}$ & CD & WB \\
\hline Work Stress (WS) & $\begin{array}{l}\text { Pearson Correlation } \\
\text { Sig. (2-tailed) } \\
\text { N }\end{array}$ & 152 & $\begin{array}{l}.794 * * \\
\\
.000 \\
152 \\
\end{array}$ & $\begin{array}{l}. .251 * * \\
.002 \\
152\end{array}$ & $\begin{array}{l}-.166^{*} \\
.040 \\
152\end{array}$ & $\begin{array}{l}-.183 * \\
\\
.024 \\
152 \\
\end{array}$ \\
\hline Role Overload (RO) & $\begin{array}{l}\text { Pearson Correlation } \\
\text { Sig. (2-tailed) } \\
\text { N }\end{array}$ & $\begin{array}{l}.794^{* *} \\
.000 \\
152 \\
\end{array}$ & 152 & $\begin{array}{l}.197 * \\
\\
.015 \\
152 \\
\end{array}$ & $\begin{array}{l}-.291 * * \\
\\
.000 \\
152\end{array}$ & $\begin{array}{l}-.250 * * \\
\\
.002 \\
152 \\
\end{array}$ \\
\hline Role Ambiguity (RA) & $\begin{array}{l}\text { Pearson Correlation } \\
\text { Sig. (2-tailed) } \\
\text { N }\end{array}$ & $\begin{array}{l}.251^{* *} \\
\\
.002 \\
152\end{array}$ & $\begin{array}{l}.015 \\
152 \\
\end{array}$ & 152 & $\begin{array}{l}.350 * * \\
.000 \\
152\end{array}$ & $\begin{array}{l}.365 * * \\
.000 \\
152\end{array}$ \\
\hline $\begin{array}{l}\text { Career Development } \\
\text { (CD) }\end{array}$ & $\begin{array}{l}\text { Pearson Correlation } \\
\text { Sig. (2-tailed) } \\
\text { N }\end{array}$ & $\begin{array}{l}.040 \\
152\end{array}$ & $\begin{array}{l}.000 \\
152\end{array}$ & $\begin{array}{l}.000 \\
152\end{array}$ & 152 & $\begin{array}{r}.877 * * \\
.000 \\
152\end{array}$ \\
\hline $\begin{array}{l}\text { Work-life Balance } \\
\text { (WB) }\end{array}$ & $\begin{array}{l}\text { Pearson Correlation } \\
\text { Sig. (2-tailed) } \\
\text { N }\end{array}$ & $\begin{array}{c}-.183^{*} \\
\\
.024 \\
152\end{array}$ & $\begin{array}{l}.002 \\
152\end{array}$ & $\begin{array}{l}.000 \\
152\end{array}$ & $.877 * *$ & 152 \\
\hline
\end{tabular}

Table 2 above exhibits the correlation outcome among work stress, role overload, role ambiguity, career development, and work-life balance. The result attained found significant and positive relationship among role overload and work stress $\left(\mathrm{r}=.794^{* *}, \mathrm{n}=152, \mathrm{p} \leq 0.01\right)$. This correlation result shows that greater role overload among call center executives will lead to higher work stress. The results shows significant and positive relationship between role ambiguity and work stress $\left(\mathrm{r}=.251^{* *}, \mathrm{n}=152, \mathrm{p} \leq 0.01\right)$. The outcome for this relationship found that work stress will increase among the call center executives if role ambiguity is greater. On the other hand, career development has a weak and significant negative correlation with work stress $\left(r=-.166^{*}, \mathrm{n}\right.$ $=152, \mathrm{p} \leq 0.05)$. The relationship exposed that greater level of career development opportunities among call center executives will reduce the level of work stress in BPO Call Center. The study findings identified that work-life balance has low and significant negative relationship with work stress $\left(\mathrm{r}=-.183^{*}, \mathrm{n}=152, \mathrm{p} \leq 0.05\right)$. Therefore, high level of work-life balance will lower the work stress among the executives in the BPO Call Center.

\subsection{Multiple Regression Analysis of the Stressor on Work Stress.}

The developed hypotheses for this study are tested by conducting Multiple Regression Analysis. Multiple Regressions analysis are used to evaluate the value of contributing stress variables on work stress. Multiple regression also enable the researcher to identify the relationship among the dependent and independent variables. Multiple Regressions is an extension of bivariate correlation. R square provides a measure of how well the data points are simulated by model. 
Table 3: Multiple Linear Regression (Model Summary)

Model Summary

\begin{tabular}{|c|l|r|r|r|}
\hline Model & $R$ & $R$ Square & $\begin{array}{c}\text { Adjusted } R \\
\text { Square }\end{array}$ & $\begin{array}{c}\text { Std. Error of } \\
\text { the Estimate }\end{array}$ \\
\hline 1 & $.807^{a}$ & .651 & .641 & 3.69462 \\
\hline
\end{tabular}

a. Predictors: (Constant), WB, roleoverload, roleambiguity, careerdevelopment

b. Dependent Variable: workstress

Table 3 indicates that the coefficient of determination value $\left(R^{2}\right)$ is equal to 0.651 . Therefore, the $R$ Square value of 65 percent means variations of work stress can be explained by the four independent variables (role overload, role ambiguity, and career development and work-life balance). However, it identified that $35 \%$ variation of the work stress remained unexplained under this model and can be explained by other variables. Based on Table 3 , the $\mathrm{R}$-square present that $65.1 \%$ of the variation in work stress is identified contributing factors of work stress such as role overload, role ambiguity, career development and work-life balance. Moreover the F value of the study demonstrate how well the model fit in overall, which is $\mathrm{F}=68.484$.

Table 4: Multiple Linear Regression Analysis (ANOVA).

\begin{tabular}{|c|c|c|c|c|c|c|}
\hline \multicolumn{7}{|c|}{ ANOVA } \\
\hline \multicolumn{2}{|c|}{ Model } & $\begin{array}{l}\text { Sum of } \\
\text { Squares }\end{array}$ & df & Mean Square & $\mathrm{F}$ & Sig. \\
\hline \multirow[t]{3}{*}{1} & Regression & 3739.303 & 4 & 934.826 & 68.484 & $.000^{a}$ \\
\hline & Residual & 2006.585 & 147 & 13.650 & & \\
\hline & Total & 5745.888 & 151 & & & \\
\hline
\end{tabular}

a. Predictors: (Constant), WB, roleoverload, roleambiguity, careerdevelopment

b. Dependent Variable: workstress

In order to determine the two populations of variances are identical, F-test is utilized. The F-test are carried out is to identify the model which best fit the population from where the data were tried and gathered. Referring to Table 4 , the F-value is 68.484 with a p-value of 0.000 . Therefore, the p-value of ANOVA is less than the significance level 0.05 and it indicates that the four independent variables have a significant relationship with work stress.

Table 5:Multiple Regression Results (Coefficient)

\begin{tabular}{|l|l|l|l|l|l|}
\hline \multirow{2}{*}{ Model } & \multicolumn{2}{|l|}{$\begin{array}{l}\text { Unstandardized } \\
\text { Coefficients }\end{array}$} & $\begin{array}{l}\text { Standardized } \\
\text { Coefficients }\end{array}$ & T & Sig \\
\cline { 2 - 5 } & $\mathbf{B}$ & Std. Error & $\mathbf{B}$ & \\
\hline Constant & 7.729 & 2.454 & & 3.150 & .002 \\
\hline Role Overload & .606 & .042 & .784 & 14.501 & .000 \\
\hline Role Ambiguity & -.122 & .069 & .099 & 1.780 & .077 \\
\hline $\begin{array}{l}\text { Career } \\
\text { Development }\end{array}$ & .141 & .070 & .209 & 2.019 & .045 \\
\hline $\begin{array}{l}\text { Work-life } \\
\text { Balance }\end{array}$ & -.287 & .142 & -.207 & -2.025 & .045 \\
\hline
\end{tabular}

Dependent variable: Work Stress.

R Square $=.651$

$\mathrm{F}=68.484$

${ }^{*} \mathrm{p} \leq 0.05$ 
The four independent variable as shown on Table 5, together, explain 65 percent of the variance on stress. Role overload seems to have the greatest influence on stress, judged by the Beta weight of .784 which is the highest, followed by career development Beta of .21. Work-life balance also has a significant negative influence on stress (Beta of -.21). Meaning, when work-life increase stress will decrease. Role ambiguity do not individually explain the variance on stress level significantly (Beta of. $0.0770 \mathrm{p}>0.05$ ). So stress will increase if role overload and career development are increase. But for work life balance when it is increase the stress level of the call center executive in BPO decreased. It can be summarized that, role overload, career development and work-life balance are appropriate variables to analyze work stress among call center executives in BPO but role ambiguity has not effect.

\subsection{DISCUSSION}

Work stress is a global issue that keeps rising among the working adults. The fast growing business pace has created a highly demanding and stressful working environment. Work stress is phenomena that are extremely threaten for both organization and employees. From the result generated it has been indicated that role overload is the major contributor of work stress for the BPO call center executive in Selangor. BPO call center management must find solutions to get rid of role overload in BPO call center customer service executives and reduce their work stress. Based on previous researches, it has been proved that role overload is the leading contributor of work stress among the call center executive. Many researches has been discuss the relationship between role overload and work stress among employee. BPO management should take it as a serious issue and come up with some effective ways to overcome the problems related to work stress.

\subsection{Recommendation for future studies}

In order to create a better research in future, upcoming researcher should spend a lengthier time for data collection so that larger amount of feedback can be collected for better result analysis. Future researchers are fortified to conduct survey using other type of data collection methods beside Google survey in hope for higher response rate. A representative sample from different states, different industry and different specialization needs to be obtaining for better generalizability to the population at large. Longitudinal study is also suggested in order to determine the causal relationship and to recognize whether variable impacts vary over the time.

\subsection{Conclusion}

The result of the research shows significant and positive relationship between role ambiguity and work stress. The outcome for this relationship found that work stress will increase among the call center executives if role ambiguity is greater. On the other hand, career development has a weak and significant negative correlation with work stress. The relationship exposed that greater level of career development opportunities among call center executives will reduce the level of work stress in BPO Call Center. The study findings identified that work-life balance has low and significant negative relationship with work stress. The high level of work-life balance will lower the work stress among the executives in the BPO Call Center. This research has also successfully discovered the effect of four independent variables that caused work stress among executives in Business Process Outsourcing Call Center in Selangor. Role overload seems to have the greatest influence on stress. Consequently, this value had discovered that role overload, role ambiguity, career development and work-life balance (independent variables) have $65.1 \%$ of impact on work stress (dependent variable) among the executives in BPO Call Center, Selangor. It can be summarized that, role overload, career development and work-life balance are appropriate variables to analyze work stress among call center executives in BPO. But role ambiguity do not individually explain the variance on stress level significantly

\section{BIBLIOGRAPHY}

1. Aziz, S., \& Cunningham, J. (2008). Workaholism, work stress, work-life imbalance: exploring gender's role. Gender in Management: An International Journal, 23(8), 553-566.

2. Conley, S., \& Woosley, S. A. (2000). Teacher role stress, higher order needs and work outcomes. Journal of Educational Administration, 38(2), 179-201.

3. Creswell, J. W. (2003). A qualitative, quantitative, and mixed method approaches (2nd Ed.). Thousand Oaks, CA: Sage.

4. Day, A. L., \& Livingstone, H. A. (2001). Chronic and acute stressors among military personnel: do coping styles buffer their negative impact on 
International Journal of Trend in Scientific Research and Development (IJTSRD) ISSN: 2456-6470

health?. Journal of occupational health psychology, 6(4), 348.

5. David, W. (2014, July 31). Malaysian outsourcing sector's overseas revenue up to $27 \%$ in 2013. Retrieved from: https://www.digitalnewsasia.com/digital-economy/ malaysian-outsourcing-sectors-overseas-revenueup-27pc-in-2013.

6. Fox, M. L. \& Dwyer, D. J. (2006). The relationship between job demands and key performance indicators: Moderating effects of job resources in call centers. Journal of Business and Management, 12(2), 127.

7. Ivancevich, J. \& Matteson, M. (2002). Organizational Behaviour and Management (6th edition). New York: McGraw-Hill.

8. Johnson, S., Cooper, C., Cartwright, S., Donald, I., Taylor, P., \& Millet, C. (2005). The experience of work-related stress across occupations. Journal of managerial psychology, 20(2), 178-187.

9. Krejcie, R. V., \& Morgan, D. W. (1970). Determining sample size for research activities. Educational and psychological measurement, 30(3), 607-610.

10. Leedy, P. \& Ormrod, J. (2001). Practical research: Planning and design (7th ed.). Upper Saddle River, NJ: Merrill Prentice Hall. Thousand Oaks: SAGE Publications.

11. Michie, S. (2002). Causes and management of stress at work. Journal of Occupational and Environmental Medicine, 59(1), 67-72.

12. Mike (2013). BPO companies in Malaysia transforming the region into a BPO powerhouse. Retrieved from http://www.bpmwatch.com/research/bpocompanies-in-malaysia-transforming-the-regioninto-a-bpo-powerhouse/
13. Mohan, N., \& Ashok, J. (2011). Stress and depression experienced by women software professionals in Bangalore, Karnataka. Global journal of management and business research, 11(6), 24-29.

14. Ross, D., \& Vasantha, S. (2014). A conceptual study on impact of stress on work-life balance. Sai Om Journal of Commerce \& Management, 1, 6165.

15. Sukamolson, S. (2007). Fundamentals of quantitative research: Bangkok, Thailand: EJTR. Retrieved from http://www.culi.chula.ac.th/e Journal/bod/Suphat\%20Sukamolson.pdf.

16. Surinder, K. (2011). Comparative study of occupational stress among teachers of private and government schools in relation to their age, gender and teaching experiences. International Journal of Educational Planning and Administration 1(2), 151 -160 .

17. Sverke, M., Hellgren, J., \& Näswall, K. (2002). No security: a meta-analysis and review of job insecurity and its consequences. Journal of occupational health psychology, 7(3), 242.

18. Topper, E. F. (2007). Stress in the Library, Journal of New Library, 108(11/12): 561-564.

19. Vijayalakshmi and Navneetha (2013), Work Life Balance of Women Faculty working in Educational Institutions: issues and Problems, International Journal of Research in Commerce, Economics and Management, 3(4), 73-75.

20. Wu, S., Zhu, W., Wang, Z., Wang, M., \& Lan, Y. (2007). Relationship between burnout and occupational stress among nurses in China. Journal of advanced nursing, 59(3), 233-239.

21. Zedeck, S. (1992). - Introduction: Exploring the domain of work and family concernsll. In S. Zedeck (Ed.), Work, families, and organizations (pp. 1-32). San Francisco: Jossey-Bass. 